\title{
Kelainan Genetik Klasik: Tinjauan Penciptaan Manusia dalam Perspektif Al-Qur'an
}

\author{
Nur Patria Tjahjani \\ Akademi Analis Farmasi dan Makanan 17 Agustus 1945 Semarang \\ e-mail: nurpatria@gmail.com \\ Anggun Zuhaida \\ MAN 2 Kudus \\ e-mail: anggunchemist@gmail.com
}

\begin{abstract}
Abstrak
Allah telah menciptakan manusia dari tanah dan keturunannya diciptakan dari sel sperma dan ovum, untuk membentuk zigot, embrio dan kemudian menjadi janin dan akhirnya akan lahir manusia yang akan menjadi khalifah baru di bumi. Dalam penciptaannya, manusia akan menjadi manusia sempurna atau tidak sempurna dan itu menjadi tanda-tanda kekuasaan Allah. Penyakit genetik atau kelainan genetik adalah suatu kondisi yang disebabkan oleh kelainan dari satu atau lebih gen yang menyebabkan kondisi fenotipe klinis. Hal ini dapat terjadi karena peristiwa nondisjunction, yaitu proses di mana sel telur dan sperma mereplikasi diri dan membagi. Penelitian ini difokuskan untuk mengetahui adanya kelainan-kelainan genetik pada manusia yang dilihat dalam tinjauan penciptaan manusia dalam perspektif al-Qur'an. Penelitian ini merupakan penelitian kualitatif dengan pendekatan deskriptif menggunakan metode non interaktif. Kelainan genetik yang terjadi membutuhkan serangkaian pemeriksaan dan sitogenetik molekul yang lengkap. Meskipun masalah genetik dan fisik bagi orang-orang dengan kelainan kromosom tidak dapat diatasi, pendidikan dan perawatan yang tepat setelah berkomunikasi dengan seorang konselor genetik akan meningkatkan kualitas hidup mereka.
\end{abstract}


Allah has created man from the land and his descendants were created from the sperm cell and ovum, to form a zygote, embryo and then into a fetus and eventually be born human beings who will be the new caliph in the earth. In its creation, it would be a perfect or imperfect human being and it became the signs of Allah's power. Genetic disease or genetic disorder is a condition caused by abnormalities of one or more genes that cause a clinical phenotype condition. The causes of genetic diseases are due to abnormalities of chromosome number. This can occur due to nondisjunction, which is a process in which egg and sperm self-replicate and divide. This study is focused to detect genetic abnormalities in humans is seen in the review of the creation of man in the perspective of the al-Qur'an. This research is a qualitative descriptive approach using non-interactive methods. Genetic disorder requires a series of checks and molecular cytogenetic complete. Although genetic and physical problems for people with chromosomal abnormalities can not be overcome, education and proper care after communicating with a genetic counselor will improve the quality of their lives.

Kata kunci: kelainan genetik, penciptaan manusia, al-Qur'an

\section{Pendahuluan}

Allah SWT telah menciptakan manusia itu dari tanah dan keturunannya diciptakan dari air mani atau sel sperma dan ovum yang bertemu untuk membentuk zigot, kemudian menjadi embrio dan akhirnya menjadi janin dan lahirlah manusia-manusia baru yang akan menjadi khalifah di bumi. Hal itu telah diterangkan dalam Qs. al-Fath ayat 11 yang artinya: Dan Allah menciptakan kamu dari tanah kemudian dari air mani, Kemudian dia menjadikan kamu berpasangan (laki-laki dan perempuan). dan tidak ada seorang perempuanpun mengandung dan tidak (pula) melahirkan melainkan dengan sepengetahuan-Nya. dan sekali-kali tidak dipanjangkan umur seorang yang berumur panjang dan tidak pula dikurangi umurnya, melainkan (sudah ditetapkan) dalam 
Kitab (Lauh mahfuzh). Sesungguhnya yang demikian itu bagi Allah adalah mudah.

Pada Qs. al-Mukmin ayat 67-68 yang artinya: Dia-lah yang menciptakan kamu dari tanah Kemudian dari setetes mani, sesudah itu dari segumpal darah, Kemudian dilahirkannya kamu sebagai seorang anak, Kemudian (kamu dibiarkan hidup) supaya kamu sampai kepada masa (dewasa), Kemudian (dibiarkan kamu hidup lagi) sampai tua, di antara kamu ada yang diwafatkan sebelum itu. (Kami perbuat demikian) supaya kamu sampai kepada ajal yang ditentukan dan supaya kamu memahami(nya). Dia-lah yang menghidupkan dan mematikan, Maka apabila dia menetapkan sesuatu urusan, dia Hanya bekata kepadanya: "Jadilah", Maka jadilah ia.

Dalam surat di atas ditafsirkan Allah SWT menciptakan manusia dari air mani menjadikannya janin kemudian berkembang menjadi dewasa. Dan ada suatu saat dimana manusia akan mati . Dan semua itu sangat mudah bagi Allah SWT untuk melakukan yang demikian.

Sebagaimana ayat-ayat dalam al-Qur'an di atas mudah bagi Allah SWT dalam menciptakan manusia yang normal dan mudah pula bagi Allah SWT menciptakan manusia yang mengalami abnormalitas atau kelainan genetika, sehingga orang tersebut akan tampak lain atau "aneh" bila dibandingkan dengan orang yang normal. Kelainan genetik adalah suatu kondisi yang disebabkan oleh kelainan satu atau lebih gen yang menyebabkan sebuah kondisi fenotip klinis. Penyebab penyakit genetik antara lain adalah karena ketidaknormalan jumlah kromosom (Sindrom Down, Sindrom Klinefelter, dan Sindrom Turner) mutasi gen yang 
berulang (Penyakit Huntington), gen yang rusak dan diturunkan oleh orangtua. Sindrom Down, Sindrom Klinefelter dan Sindrom Turner merupakan kelainan kromosom klasik, yang telah ditemukan pada akhir abad ke 19 (Fidler, 2005: 92).

Sitogenetika atau genetika sel berasal dari kata sitologi (ilmu tentang sel) dan genetika, sehingga sitogenetika dapat diibaratkan gabungan antara sitologi dan genetika. Ilmu pengetahuan genetika dasar mempelajari karakter atau sifat makhluk hidup secara kuantitatif maupun kualitatif beserta pewarisannya. Oleh karena itu ilmu sitogenetika dapat digunakan untuk mempelajari dan menganalisis pewarisan sifat. Pewarisan makhluk hidup dibawa oleh gen yang terdapat di dalam kromosom. Kromosom diketahui menjadi tempat utama dari materi genetik yaitu sifat DNA dan RNA. Bentuk kromosom, struktur kromosom, serta evolusi kromosom, menjadi dasar ilmu sitogenetika. Ilmu Sitogcnetika juga mempelajari berbagai macam kelainan kromosom yang muncul pada makhluk hidup (Suryo, 1995: 42).

Kelainan kromosom pada penderita menimbulkan variasi jumlah kromosom bila dibandingkan dengan orang normal, yang mempunyai karyotype 46, XX (pada wanita) atau 46, XY (pada pria). Pada sindrom Down dengan trisomi 21 mempunyai karyotype 47, XX +21 atau 47,XY+21, sindrom Klinefelter 47,XXY. Hal tersebut dapat terjadi karena peristiwa nondisjunction yaitu kegagalan sepasang kromosom untuk memisahkan selama meiosis, yang merupakan proses di mana sel telur dan sperma mereplikasi diri dan membagi. Akibat kegagalan ini 
gamet (sel telur dan sperma) menghasilkan tambahan salinan kromosom pada autosom atau gametosom.

Kelainan kromosom ini dapat diturunkan dari orang tua ataupun terjadi secara de novo dan berkontribusi besar terhadap terjadinya cacat lahir pada bayi. Kelainan kromosom menjadi salah satu masalah yang menjadi perhatian publik dan para ilmuwan pada saat ini. Berbagai mutasi yang terjadi pada kromosom menyebabkan banyaknya cacat bawaan yang terlihat dan menjadi masalah yang tidak dimengerti oleh masyarakat. Kelainan kromosom dapat dianalisis dengan melihat karyotype kromosom. Karyotype kromosom merupakan gambaran lengkap dari kromosom pada tahap metafase dari suatu sel yang tersusun secara teratur dan merupakan pasangan-pasangan dari sel diploid yang normal (Alresna, 2009: 37).

Metode yang digunakan untuk melihat karyotype kromosom atau gamabran kromosom adalah karyotyping. Karyotyping adalah analisis yang menggunakan mikroskop untuk menyusun karyotype kromosom yang dapat digunakan untuk memeriksa jumlah abnormal kromosom atau kromosom cacat yang terkait dengan beberapa kelainan bawaan atau syndrome (Campbell, 2008: 295).

Sindrom Turner disebabkan oleh hilangnya satu kromosom $\mathrm{X}$ yang berasal dari ayah dalam sel janin, sehingga menghasilkan konsepsi perempuan dengan 45 kromosom. Janin yang mengalami abortus spontan di awal kehamilan lebih dari 95\% kasus (Frias, 2003:3) . Sedangkan janin yang dapat bertahan sampai trimester kedua janin dapat dideteksi 
dengan Ultrasonografi biasanya mengalami masalah kesehatan yang serius, seperti Higroma sistik, ascites, dan hidrosefalus.

Penderita kelainan kromosom klasik mempunyai fenotip fisik yang berbeda dengan orang-orang normal, kemungkinan akan memperoleh berbagai masalah kesehatan, intelegensia yang lebih rendah dari orang normal dan juga masalah sosial dengan lingkungannya bahkan dengan keluarganya. Perawatan bagi penderita sedini mungkin sejak dalam kandungan, awal kelahiran, dukungan keluarga yang cukup, latihan fisik, vokasional akan mampu meningkatkan kualitas kehidupan penderita sindroma tersebut. Keluarga penderita dalam hal ini orangtua sangat membutuhkan informasi yang lengkap tentang penyakit ini dan pewarisannya, untuk itulah dibutuhkan konseling genetika dengan konselor genetika yang professional.

Manusia normal dipandang sebagai makhluk unggulan atau puncak penciptaan Tuhan. Keunggulannya terletak pada wujud kejadiannya sebagai makhluk yang diciptakan dengan sebaik-baik penciptaan. Lalu bagaimana dengan manusia yang telah diqodar Allah SWT, menjadi manusia yang mempunyai kelainan genetika? Maka yang diciptakan normal wajib selalu bersyukur atas segala kenikmatan yang telah Allah SWT limpahkan kepadanya. Tugas manusia normal untuk membantu sesamanya yang berkekurangan dengan inisiatif moralnya untuk meningkatkan kualitas hidup sesamanya agar lebih baik. Pandangan Islam mengenai arti hidup, sangat berlainan dengan pandangan orang-orang yang berpandangan kebendaan samata-mata (materialistis). Dengan demikian tujuan hidup manusia menurut islam 
adalah menyerahkan diri untuk mencapai kebahagiaan dunia, ahirat, jasmani, dan rohani, yang dalam pelaksanaannya, materi sebagai alat, sedangkan rohani sebagai pengaruh. Sehingga bagi orang orang yang kurang beruntung bisa jadi menjadi ladang amal ibadah kita. Dengan dilandasi ketaqwaan dan kecintaan kita kepada Allah SWT maka dengan ilmu pengetahuan yang manusia kuasai, pendidikan bagi orang yang menderita kelainan genetika, memahami kondisi psikososial penderita dan keluarganya akan sangat membantu. Meskipun masalah genetik dan fisik bagi penderita kelainan genetika tidak dapat diatasi, pendidikan, serta perawatan yang tepat setelah berkomunikasi dengan konselor genetik akan meningkatkan kualitas kehidupan mereka.

Penelitian ini difokuskan untuk mengetahui adanya kelainankelainan genetik pada manusia yang dilihat dalam tinjauan penciptaan manusia dalam perspektif al-Qur'an. Selain itu juga dilihat bagaimana mengatasi kelainan tersebut serta bagaimana perawatan yang tepat untuk mengurangi kelainan tersebut.

\section{Metode Penelitian}

Penelitian ini merupakan penelitian kualitatif dengan pendekatan deskriptif. Penelitian ini menggunakan metode non interaktif. Metode non interaktif meliputi observasi dan analisis dalam dokumen. Teknik analisis data dalam penelitian ini deskriptif-eksploratif-analisis. 


\section{Pembahasan}

\section{Kromosom}

Kromosom adalah struktur dalam sel yang mengandung infomasi genetik. Kromosom manusia nomal terdiri dari 22 pasang kromosom autosom dan kromosom gonosom, baik XX maupun $\mathrm{XY}$. Kromosom mempunyai bagian yang menyempit sepasang yaitu sentromer dan membagi kromosom menjadi dua lengan yaitu lengan $\mathrm{p}$ pada bagian atas dan lengan $\mathrm{q}$ di bagian bawah. Berdasarkan letak sentromernya kromosom dapat dibedakan menjadi beberapa bentuk. Pertama kromosom metasentrik yaitu apabila sentromer terletak di tengah kromosom sehingga kromosom terbagi menjadi dua lengan yang hampir sama panjang. Kedua kromosom submetasentrik yaitu apabila sentromer terletak ke arah salah satu ujung kromosom sehingga kromosom terbagi menjadi dua lengan yang tak sama panjang. Ketiga kromosom akrosentik yaitu letak sentromer di dekat ujung kromosom sehingga satu lengan menjadi sangat pendek dan yang lain sangat panjang. Terakhir adalah kromosom telosentrik yaitu apabila sentromer terletak di ujung kromosom sehingga kromosom hanya terdiri dari satu lengan saja (Suryo, 2015: 48).

Dalam buku Internasional System for Human Cytogenetics Nomenclature (ISCN) kromosom manusia dikelompokkan menjadi 7 kelompok utama (ISCN, 2009): Kelompok A (Kromosom 1-3) yaitu kromosom metasentrik berukuran besar dan mudah dibedakan dengan yang lain karena ukurannya dan letak sentromernya, Kelompok B (Kromosom 4-5) yaitu kromosom submetasentrik berukuran besar, 
Kelompok C (Kromosom 6-12) yaitu kromosom metasentrik dan submetasentrik berukuran sedang, Kelompok D (Kromosom 13-15) yaitu kromosom akrosentrik berukuran sedang dan memiliki satelit, Kelompok E (Kromosom 16-18) yaitu kromosom metasentrik dan submetrasentrik berukuran kecil, Kelompok F (Kromosom 19-20) yaitu kromosom metasentrik berukuran sangat kecil dan Kelompok G (Kromosom 21-22) yaitu kromosom akrosentrik berukuran sangat kecil dan memiliki satelit kecuali kromosom Y.

Kromosom pertama kali ditemukan pada akhir abad ke sembilan belas. Kromosom berasal dari kata Yunani Chrom yang artinya warna dan soma berarti tubuh. Kata ini dicetuskan oleh ahli-ahli anatomi Jerman yaitu Willhelm von Gottfried Waldeyer-Hartz (Gardnert, 2012: 3). Itulah awal mulanya bahwa benda-benda halus berbentuk batang panjang atau pendek dan lurus atau bengkok yang terdapat dalam inti sel dan dapat diwarnai adalah pembawa sifat keturunan (Santosa, 2009: 63).

Dengan perkembangan teknik pewarnaan pada tahun 1980an dan 1990an (Gardnet, 2012: 4), kromosom terlihat seperti pita terang dan gelap yang disebut karyotype (Green, 2011: 132). Karyotype dapat membantu mengidentifikasi kelainan kromosom dalam hal jumlahnya atau struktur kromosom (Green, 2011: 135).

\section{Morfologi Kromosom}

Dalam sel tubuh manusia yang berinti sel, di dalamnya terdapat 46 kromosom (Knight, 2003: 107). Dari ke-46 kromosom ada pasangan kromosom dengan morfologi serupa, sehingga dikenal pasangan ke-1, 
pasangan ke-2 dan seterusnya hingga ke pasangan ke-23, sehingga secara sistematis membagi kromosom pada sel somatik menjadi 2 tipe, yaitu:

Autosom (kromosom somatis), berjumlah 22 pasang (44 buah) dan tidak berhubungan dengan penentuan jenis kelamin.Gonosom (kromosom seks) berjumlah sepasang (2 buah) yaitu $X$ dan $X$ untuk wanita serta $\mathrm{X}$ dan $\mathrm{Y}$ untuk laki-laki. Kromosom ini berhubungan dengan jenis kelamin (Santosa, 2009: 74).

Gambar 1. Karyotype kromosom laki-laki (Santosa, 2009: 74).

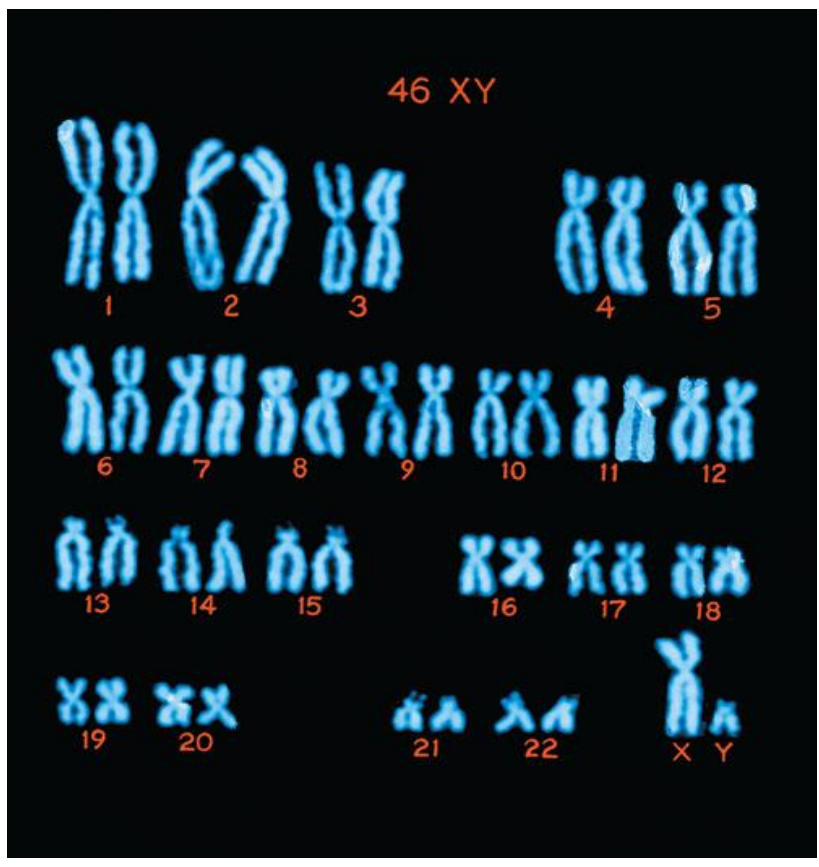

Karyotype ini dapat membantu mengidentifikasi kelainan kromosom dengan jelas, baik kelainan dalam jumlah kromosom maupun struktur kromosom (Mandal, 2013: 3). 


\section{Pembelahan Sel}

Proses pembelahan sel merupakan bagian integral dari siklus sel (cell cycle), kehidupan sel yang dimulai dari saat pertama kali terbentuk dari sel induk yang membelah menjadi dua sel dan meneruskan materi genetik yang identik ke sel anakan. Pada tahun 1882, seorang ahli anatomiJerman yang bernama Walther Flemming mengembangkan zat pewarna yang memungkinkan ia mengamati, untuk pertama kali perilaku kromosom selama mitosis dan sitokinesis. Flemming mencetuskan istilah mitosis dan kromatin (Campbell, 2008: 286). Tahun 1884, Strasburger mengenakan istilah profase, metafase dan anafase untuk pembagian saat pembelahan sel (Arnold, 1973: 52).

Siklus sel terbagi menjadi 2 fase yaitu fase mitotik (mitotic phase) dan fase interfase (interphase). Fase mitosis mencakup sitokinesis merupakan bagian terpendek dari siklus sel sedangkan interfase merupakan tahapan yang panjang dari siklus sel, yang biasanya mencakup 90\% siklus sel. Pada saat interfase sel bertumbuh dan membuat salinan kromosom-kromosom sebagai persiapan pembelahan sel. Interfase dibagi menjadi beberapa subfase: fase G1 (first gap), fase $\mathrm{S}$ (sintesis), dan fase G2 (second gap). Selama ketiga subfase, sel bertumbuh dengan cara menghasilkan protein organel sitoplasma seperti mitokondria dan retikulum endoplasma (Campbell, 2008: 288). Secara konvensional mitosis dibagi menjadi lima tahap: profase (prophase), prometafase (prometaphase), metafase (metaphase), anafase (anaphase), dan telofase (telophase). Sitokinesis yang bertumpang-tindih dengan tahapan akhir mitosis, menyelesaikan fase mitotik (campbell, 2008: 299). 
Tahun 1888 Waldeyer menemukan struktur benang-benang kromosom yang dapat dilihat selama pada mitosis (Koshland, 1994: 102). Fase yang terlihat jelas kromosomnya adalah pada tahap metafase. Metafase merupakan tahap mitosis yang paling lama, seringkali berlangsung sekitar 20 menit. Sentromer kini berada pada kutub-kutub sel yang berseberangan. Kromosom bersejajar pada lempeng metafase bidang ekuator yang berada di pertengahan jarak antara kedua kutub gelendong. Setiap kromosom, kinetokor pada sister kromatide melekat ke mikrotubulus kinetokor yang berasal dari kutub yang berseberangan (Campbell, 2008: 288). Selama metafase dan prometafase, kromosom dapat dilihat di bawah mikroskop cahay dengan mempunyai ciri khas struktur yang panjang, dengan panjang 3-7 $\mu \mathrm{m}$ (Koshland, 1994: 112).

\section{Kelainan Kromosom}

Secara garis besar, kelainan kromosom dapt dibedakan menjadi dua, kelainan numerik dan kelainan struktural. Kelainan kromosom numerik merupakan hilangnya atau bertambahnya satu set kromosom (secara keseluruhan) yang disebabkan terjadi kesalahan dalam pemisahan kromosom homolog atau nondisjunction pada fase meiosis I dan II. Diantaranya adalah monosomi: hilangnya satu kromosom pada sepasang kromosom. Trisomi yaitu bertambahnya satu kromosom pada sepasang kromosom. Polyploidi yaitu satu sel terdapat banyak kromosom haploid. Mosaik yaitu adanya dua/lebih macam sel pada individu atau jaringan yang berbeda aturan genetiknya namun tetap diturunkan dari zigot yang sama, jadi memiliki asal genetik yang sama (mosaikisme). 
Kelainan kromosom struktural disebabkan karena kesalahan ketika proses penyatuan yang terjadi pada crossing over pada meiosis I. Translokasi yaitu berpindahnya materi kromosom antara kromosom yang satu dengan lainnya. Pertukaran ini biasanya tidak disertai dengan hilangnya DNA sehingga disebut balanced translocation, di mana secara klinis individu tersebut terlihat normal. Namun pada pembawa kromosom balanced translocation akan memberikan keturunan dengan translocation imbalans/tidak seimbang yang sangat memungkinkan juga disertai hilangnya DNA. Delesi adalah hilangnya bagian dari sebuah kromosom dan berakibat pada monosomi untuk segmen kromosom tersebut. Delesi dapat terjadi pada 2 level, delesi kromosom yang luas dan dapat dilihat mikroskop. Sedangkan mikrodelesi yang bersifat submikroskopik dapat diidentifikasi dengan menggunakan fluorescent in siti hybridization (FISH) dan pemeriksaan molekuler yang lainnya. Insersi yaitu terjadi karena segmen dari salah satu kromosom masuk ke dalam kromosom yang lain. Duplikasi yaitu adanya dua salinan salah satu segmen kromosom pada satu kromosom. Inversi yaitu terjadi akibat adanya dua patahan pada satu kromosom yang kemudian patahan tersebut memutar terbalik dengan sudut $180^{\circ}$ atau bertukar posisi. Inversi parasentrik bila patahan ininpada salah satu lengan dan tak termasuk sentromernya. Inversi perisentrik bila patahan pada salah satu tepi dari sentromer. Isokromosom yaitu terjadinya delesi pada salah satu lengan digantikan oleh duplikasi dari lengan yang lain, sehingga biasanya lengan panjang atau lengan pendek menjadi identik (Turnpenny, 2007: 22). 
Kelainan kromosom yang banyak ditemui dalam klinik medis berasal dari kelainan selama pembentukan sel benih, terutama saat meiosis selama gametogenesis. Selain itu, dapat juga terjadi saat poszigotik, pembelahan mitosis selama masa embrio yang dapat menghasilkan kondisi mosaikisme. Meiosis bertujuan untuk mereduksi jumlah kromosom pada sel punca gonad dari kondisi diploid $(2 \mathrm{n}=46)$ menjadi haploid pada gamet $(n=23)$. Meiosis terdiri dari dua tahap, yaitu meiosis I dan II, meiosis I secara umum terdiri dari tiga tahap, sinapsis, pindah silang (crossing over), dan pemisahan (disjunction) (Suryo, 1995: $38)$.

Kondisi patologis pada kromosom dapat muncul pada proses disjunction, yaitu pada kondisi nondisjunction dan malsegregasi. Disjunction merupakan segregasi normal pada kromosom homolog atau kromatoid ke arah kutub pada saat pembelahan meiosis dan mitosis. Nondisjunction merupakan kegagalan proses tersebut, dan dua kromosom atau kromatid akan kearah hanya salah satu kutub. Nondisjunction terjadi secara spontan, proses molekuler yang mendasarinya secara tepat belum banyak diketahui. Nondisjunction lebih sering terjadi pada fase meiosis I. Nondisjunction pada meiosis menghasilkan gamet dengan 22 atau 24 kromosom, di mana setelah fertilisasi dengan gamet normal akan menghasilkan zigot trisomi dan monosomi. Nondisjunction merupakan penyebab aneuploidi yang paling sering (Suryo, 1995: 44).

Kelainan kromosom (Chromosome Abnormalities) mencerminkan perubahan atau penyimpangan jumlah kromosom maupun struktur kromosom (Theisen, 2010: 162) merupakan akar dari kelainan genetis 
dan sifat (Mandal, 2013: 2). Kelainan kromosom sering menimbulkan cacat lahir dan kondisi bawaan selama hidup penderita (Mandal, 2013: 2).

Kelainan kromosom biasanya terjadi ketika ada kesalahan dalam pembelahan sel. Ada dua jenis pembelahan sel (Theisen, 2010: 159):

Mitosis terjadi pada sel somatik. Tiap sel mengandung 2 genom/diploid/2n dan pembelahan menghasilkan 2 sel dengan sifat genetik yang sama (Santosa, 2009: 72).

Meiosis

Pembelahan meiosis berguna untuk menghasilkan gamet atau selsel kelamin, sehingga lazim dikenal dengan gametogenesis. Pada pembelahan jenis ini dihasilkan sel yang menghasilkan 1 genom/haploid/n. Gametogenesis pada pria menghasilkan 4 spermatozoa dan pada wanita menghasilkan 1 ovum disertai 2 atau 3 badan polar. Gametogenesis pada wanita dinamakan oogenesis (Santosa, 2009: 72).
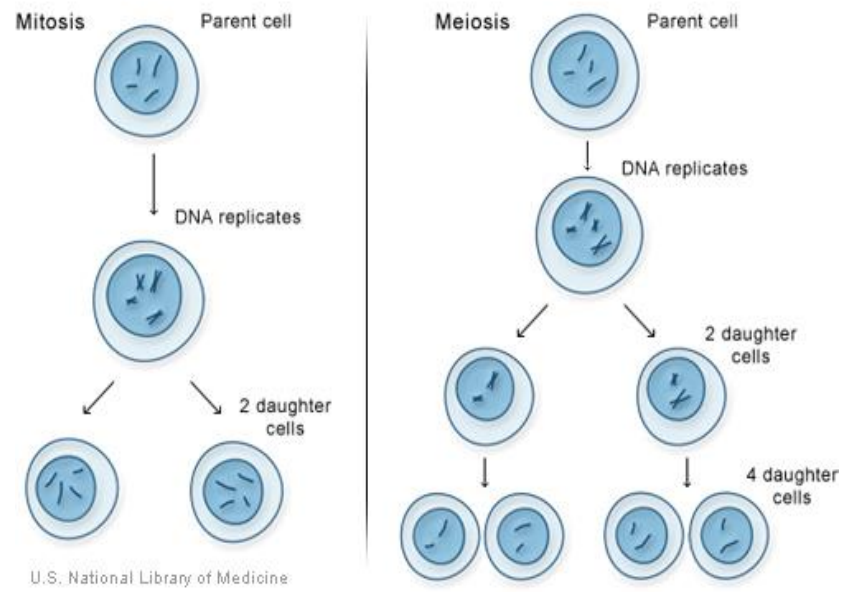

Gambar 2. Peristiwa Mitosis dan meiosis 


\section{Sindrom Down}

Pada akhir abad ke sembilan belas John Langdon Down seorang dokter yang berasal dari Inggris menerbitkan suatu publikasi yang akurat untuk menggambarkan Sindrom Down. Sehingga beliau dijuluki "Bapak Sindrom Down"(Fidler, 2015: 96).

Pada tahun 1959 seorang dokter Perancis bernama Jerome Lejeune mengidentifikasi Sindrom Down sebagai anomali kromosom (Theisen, 2010: 169). Jika sel manusia normal terdapat 46 kromosom, pada penderita Sindrom Down terdapat 47 kromosomdengan tambahan salinan kromosom 21, atau dikenal dengan trisomi 21 (Zaccharin, 2011: 2).

Sindrom Down merupakan suatu kondisi genetik, di mana ekstra kromosom 21 dapat dideteksi dengan prosedur yang disebut karyotipe (Santosa, 2009: 45). Sembilan puluh lima persen dari kejadian sindrom Down merupakan trisomi 21 (47, XX+21 atau 47, XY+21) (Wellesley, 2011: 2). Sindrom Down biasanya disebabkan oleh kesalahan dalam pembelahan sel yang disebut dengan Nondisjunction (Knight, 2003: 107).

Nondisjunction adalah kegagalan sepasang kromosom untuk memisahkan

selama meiosis, yang merupakan proses di mana sel telur dan sperma mereplikasi diri dan membagi. Akibat kegagalan ini gamet ( sel telur dan sperma) dihasilkan dengan tambahan salinan kromosom nomor 21, sehingga embrio mempunyai 47 kromosom dengan tiga salinan kromosom 21 (Kingston, 2002: 25). 
Mengapa nondisjunction terjadi sampai saat ini tidak diketahui, meskipun penelitian telah menunjukkan bahwa kenaikan frekuensi kejadian terkait dengan usia ibu. Namun, banyak orang terkejut menemukan bahwa 80 persen dari anak yang lahir dengan sindrom Down dilahirkan oleh wanita yang berusia di bawah 35 tahun. Resiko kelahiran anak-anak dengan Sindrom Down meningkat dengan bertambahnya usia ibu. Jika seorang wanita pernah melahirkan bayi dengan Sindrom Down, diperkirakan bahwa resiko memiliki anak kedua dengan Sindrom Down kemungkinan 1 kelahiran diantara 100 kelahiran normal (Fidler, 2005: 90).

Gambar 3. Peristiwa Nondisjunction pada Meiosis I dan II

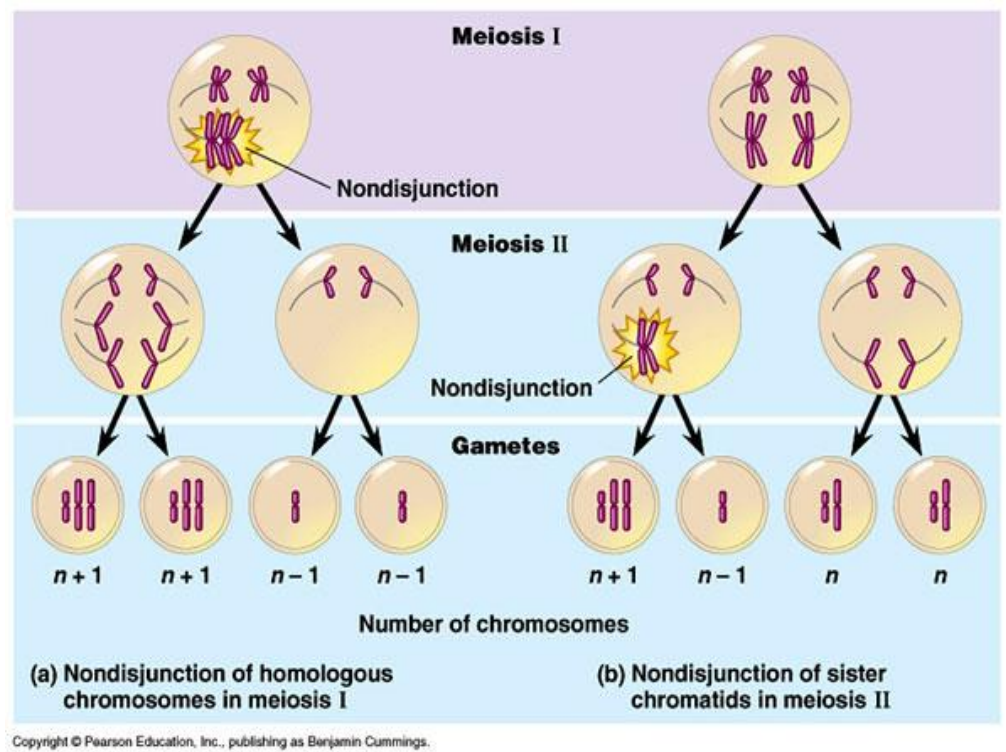

Ciri-ciri penderita Sindrom Down, mereka yang mempunyai sindrom Down mempunyai sebagian atau keseluruhan ciri-ciri berikut: mata bujur dengan lipatan epikanthik pada sudut dalam mata, otot 
hypotonia rendah, batang hidung leper, satu garis di tapak tangan (garis simian), lidah terjulur ( disebabkan rongga mulut kecil dan lidah membengkak, intelegensia (IQ) rendah (50-70), sedangkan pada mosaicism mempunyai IQ yang lebih tinggi 10-30 poin (Gardnet, 2012: 4).

Masalah kesehatan orang dengan Sindrom Down, orang dengan Sindrom Down akan meningkatkan masalah kesehatan tertentu, seperti cacat jantung bawaan, peningkatan kerentanan terhadap infeksi, masalah dengan pernafasan dan pendengaran, terhambatnya saluran pencernaan dan leukemia pada masa anak-anak terjadi dengan frekuensi yang lebih besar pada anak-anak dengan Sindrom Down dibandingkan dengan anakanak yang normal.

Pada orang dewasa terjadi peningkatan resiko penyakit Alzheimer serta kondisi tiroid. Saat ini mayoritas orang yang lahir dengan sindrom Down memiliki harapan hidup rata-rata sampai usia 55 tahun (Kingston, 2002: 25).

\section{Sindrom Klinefelter}

Sindrom Klinefelter adalah kondisi kromosom XX yang dijelaskan oleh Dr. Harry Klinefelter dari Boston Massachusetts pada tahun 1942. Anak laki-laki dengan Sindrom Klinefelter memiliki dua atau lebih X kromosom pada setiap sel, dan sebuah kromosom Y juga selalu ada, sehingga orang yang mempunyai kondisi ini adalah laki-laki (Zaccharin, 2011: 3).

Hampir semua anak laki-laki dengan Sindrom Klinefelter memiliki testis kecil dan fungsi fisik yang berkurang. Penderita dengan 
Sindro Klinefelter dapat didiagnosia pada masa bayi atau pada anak usia dini tetapi diagnosis mungkin saja tertunda hingga dewasa ketika mencari informasi tentang keadaannya yang infertilitas (Zaccharin, 2011: 3).

XXY Karyotipe Sindrom Klinefelter terjadi pada 1 diantara 600 anak laki-laki yang lahir hidup. Keadaan ini terjadi karena peristiwa nondisjunction dan kromosom tambahan kemungkinan berasal dari kromosom $\mathrm{X}$ ibu atau $\mathrm{X}$ ayah. Pada kasus ini tidak ada peningkatan keguguran dini dengan kariotipe ini dan banyak kasus yang tidak terdiagnosa.

Ciri utama dari dari Sindrom Klinefelter adalah hipogonadisme. Perkembangan saat pubertas biasanya dimulai secara spontan, tetapi ukuran testis menurun. Pada laki - laki dengan Sindrom Klinefelter memerlukan testosterone pengganti dan keadaannya infertile. Perawakan orang yang mengalami Sindrom Klinefelter biasanya normal, kadang juga lebih tinggi daripada orang yang normal. Orang dengan sindrom ini biasanya dalam keadaan ginekomastia ( payudara membesar ). Resiko terkena kanker payudara juga meningkat dibandingkan dengan laki-laki normal XY (Zaccharin, 2011: 3). Intelegensia (IQ) pada umumnya masih dalam kisaran normal, tetapi biasanya 10 - 15 tingkat lebih rendah dari saudaranya yang normal. Kesulitan belajar merupakan gangguan yang cukup umum dan mereka mempunyai perilaku yang terkait dengan keadaan lingkungannya yaitu stress, malu, ketidakdewasaan serta frustasi. Keadaan tersebut akan membaik setelah diberi terapi penggantian testosterone. Kesulitan yang utama adalah kesulitan komunikasi dan bahasa. 
Ketika sampai pada pubertas mereka mempunyai kaki yang relative panjang, otot agak langsing, rambut jarang dan pinggul relative luas, tetapi secara umum dari segi penampilan mereka adalah laki-laki (Zaccharin, 2011: 3).

Sindrom Klinefelter dikaitkan dengan resiko sejumlah kondisi medis, sehingga anak laki-laki dan laki-laki dengan sindroma tersebut harus melakukan pemeriksaan medis yang teratur dan tes skrining setiap 1-2 tahun sekali. Kemungkinan menderita Diabetes, Tiroidis Hashimoto, leukimia , limfoma, tumor dan kanker testis merupakan resiko masalah kesehatan dari Sindroma Klinefelter. Meskipun kanker payudara merupakan kondisi yang langka, tapi di masa lalu sering ditemukan pada penderita dengan Sindroma Klinefelter. Untuk saat ini dengan kemajuan ilmu kedokteran jaringan payudara yang ada diberi terapi testosterone, cenderung menghilang cukup pesat atau dengan melakukan pembedahan pada jaringan yang tidak diinginkan (Zaccharin, 2011: 4).

\section{Sindrom Turner}

Sindrom Turner disebabkan oleh hilangnya satu kromosom $\mathrm{X}$ yang berasal dari ayah dalam sel janin, sehingga menghasilkan konsepsi perempuan dengan 45 kromosom. Janin yang mengalami abortus spontan di awal kehamilan lebih dari $95 \%$ kasus. Sedangkan janin yang dapat bertahan sampai trimester kedua janin dapat dideteksi dengan Ultrasonografi, menunjukkan terjadi Higroma kistik, Chylothorax, Ascites dan Hidrocephalus. Insiden Sindrom Turner yang hidup adalah 1 dalam 2500 kelahiran. Kelainan fenotipik bervariasi tetapi biasanya ringan, kelainan lymphodema pada tangan dan kaki, bertubuh pendek dan 
infertilitas dari gonad, terdapat anyaman di leher, dada bidang, anomaly ginjal dan terjadi masalah pada penglihatan juga. Kecerdasan atau intelegensia mereka berada dalam kisaran normal, tetapi dilaporkan ada penderita Sindroma Turner memiliki masalah pada pendidikan dan perilaku. Sering terjadi masalah kesehatan pada penderita yaitu tiroiditis , hipertensi, obesitas dan diabetes tidak tergantung insulin (Frias, 2013: 2).

Pertumbuhan dapat dirangsang dengan pengobatan dengan estrogen. Gadis dengan sindrom Turner yang memiliki mosaic kariotype $46 \mathrm{XX} / 45 \mathrm{X}$, beberapa diantaranya memiliki gonad yang normal dan kesuburan yang normal.

Sindrom Turner terjadi karena kesalahan meiosis satu yang terjadi pada gamatogenesis ayah, dan juga karena kegagalan dalam pengaturan ulang. Orang tua yang telah mempunyai anak dengan Sindroma Turner dilaporkan tidak mengalami kekambuhan ketika melahirkan anak selanjutnya (Frias, 2013: 2).

Gambar 4. Peristiwa pembelahan sel yang menghasilkan laki-laki dengan Sindrom Klinefelter dan perempuan dengan sindrom Turner.

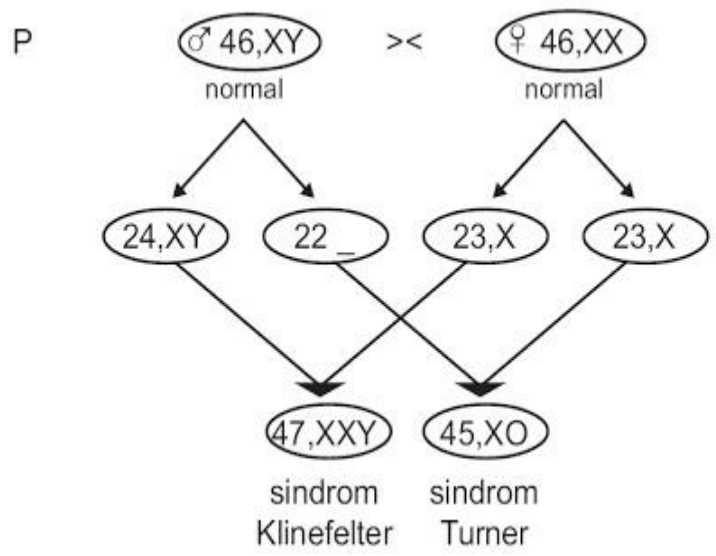




\section{Konseling Genetik}

Konseling genetik adalah komunikasi antara pasien dan keluarga dengan konselor genetik. Tujuan dari konseling genetik adalah edukatif dan psikoterapi. Konseling genetik harus didasarkan pada hasil diagnosis yang akurat dari uji prenatal maupun uji pada bayi yang baru lahir yang dicurigai mengalami kelainan kromosom dari fenotip yang terlihat (Ariani, 2010: 82). Informasi yang diberikan kepada pada pasien dan keluarganya harus memperhatikan dampak psikososial yang ditangani. Tujuan utama konseling genetik adalah untuk membantu keluarga yang beresiko genetik dapat meningkatkan kualitas hidupnya dan bereproduksi senormal mungkin (Kingston, 2002: 29).

\section{Tinjauan Penciptaan Manusia dalam Al Qur'an}

Proses kejadian manusia diterangkan dalam Qs. al-Hajj yang artinya: "Hai manusia jika kamu dalam keraguan tentang kebangkitan (dari kubur) sesungguhnya kami telah menjadikan kamu dari tanah, kemudian dari setetes mani, kemudian dari segumpal darah, kemudian dari segumpal daging yang sempurna kejadiannya dan yang tidak sempurna, agar kami jelaskan kepada kamu dan kami tetapkan dalam rahim, apa yang kami hendaki sampai waktu yang sudah ditentukan kemudian kami keluarkan kami sebagai bayi, kemudian (dengan berangsur-angsur) kamu sampailah kepada kecerdasan, dan diantara kamu ada yang diwafatkan dan (ada pula) diantara kamu yang dipanjangkan umurnya sampai pikun, supaya dia tidak mengetahui lagi sesuatupun yang dahulunya telah diketahui”. 
Dari ayat diatas dapat di simpulkan bahwa manusia terjadi dari dalam unsur yaitu unsur materi berupa mani yang kemudian berproses menjadi darah, daging, tulang, dan bentuk fisik yang sempurna, maupun tidak sempurna dan unsur rohani/roh yang dihembuskan kedalam bentuk rahim pada saat proses jasmani telah menempati usia 4 bulan/120 hari.

Manusia diciptakan oleh Allah melalui bentuk sel yang berinti itu yaitu sel kelamin seperti yang tercantum dalam Qs al-Hajj ayat 5. Dalam ayat tersebut, kata-kata " Turab " bukan berarti tanah atau debu biasa, melainkan zat renik seperti juga debu karena kecilnya yang dimaksudkan disini adalah sel, namun istilah sel ini dahulu tidak digunakan karena istilah tersebut belum dikenal, sebab kelanjutan dari ayat tersebut menyatakan bahwa sesudah dari "Turab" lalu menjadi "Nuffah" menjadi "Alaqah".

Dalam Qs. al-Nisa : 23, yang artinya: "Diharamkan atas kamu mengawini ibu-ibumu, anak perempuan, saudara-saudara perempиапти, saudara-saudara perempuan ayahmu, saudara-saudara perempuan ibumu, anak-anak perempuan dari saudara laki-lakimu, anak-anak perempuan dari saudara perempuanтu, ibu-ibu yang menyusukanmu, saudara-saudara perempuan susuan, ibu-ibu istrimu (mertua), anak-anak tiri yang dalam pemeliharaanmu, dari istri yang pernah kamu campuri; tetapi jika kamu belum mencampuri mereka, maka tidaklah berdosa atasmu (mengawini anak tiri itu), istri-istri anak kandungmu (menantu) dan mengumpulkan (mengawini) dua perempuan yang bersaudara, kecuali pada yang telah lalu. Sesungguhnya Allah Maha Pengampun lagi Maha Penyayang." 
Al-Qur'an mengharamkan bagi manusia untuk menikahi orangorang yang telah disebutkan pada ayat tersebut di atas. Ilmu genetika mengatakan bahwa jika kedua orang tua mempunyai pertalian darah satu sama lain, atau mereka memiliki hubungan kekerabatan kemudian menikah maka pernikahan itu disebut sebagai pernikahan keluarga. Keturunan yang lahir fari keduanya juga disebut keturunan dekat. Jika keduanya tidak mempunyai hubbungan apa-apa, dan masing-masing berasal dari keluarga jauh maka pernikahan itu disebut pernikahan jauh. Keturunan yang lahir dari keduanya pun disebut keturunan jauh.

Beberapa ahli telah melakukan percobaan pada beberapa generasi makhluk hidup yang berbeda di antaranya Cramb pada tahun 1883, Witsamius pada tahun 1894 dan yang lainnya. Percobaan yang mereka lakukan membuahkan hasil berupa suatu kesimpulan, yaitu perkawinan antara orang-orang yang memiliki hubungan keluarga cenderung menghasilkan keturunan yang rawan terkena penyakit. Biasanya anak yang lahir pun akan mempunyai cacat fisik.

\section{Kelainan Kromosom pada Masyarakat}

Berdasarkan insiden terjadinya abnormalitas kromosom per 10.000 kelahiran, diadaptasi dari Emery's Alement of Medical Genetics (Turnpenny, 2007: 22), bahwa Sindrom Down memiliki insidensi yang tertinggi sebesar 15 per 10.000 kelahiran, sedangkan Sindroma Turner memiliki insidensi yang terendah sebesar 1-2 per 10.000 kelahiran. 


\section{Kelainan Genetik dalam Perspektif Al-Qur'an}

Kelainan genetika pada penderita menimbulkan variasi jumlah kromosom bila dibandingkan dengan orang normal, yang mempunyai karyotype 46, XX atau 46, XY. Pada sindrom Down dengan trisomi 21 mempunyai karyotype $47, X X+21$ atau $47, X Y+21$, sindrom Klinefelter 47,XXY. Sindrom Turner mempunyai karyotype 45,X.

Keadaaan tersebut dapat terjadi karena peristiwa nondisjunction yaitu kegagalan sepasang kromosom untuk memisahkan selama meiosis, yang merupakan proses di mana sel telur dan sperma mereplikasi diri dan membagi. Akibat kegagalan ini gamet (sel telur dan sperma) menghasilkan tambahan salinan kromosom pada autosom atau gametosom. Sindrom Turner disebabkan oleh hilangnya satu kromosom $\mathrm{X}$ yang berasal dari ayah dalam sel janin.

Konseling genetika merupakan proses komunikasi yang membahas masalah-masalah yang berhubungan dengan kejadian atau resiko terulangnya penyakit yang mungkin disebabkan oleh penyakit genetik dalam keluarga. Layanan konseling genetik didahului dengan mendiagnosis etiologi kelainan membutuhkan serangkaian pemeriksaan sitogenetik dan molekuler yang lengkap. Meskipun masalah genetik dan fisik bagi penderita kelainan kromosom tidak dapat diatasi, pendidikan, serta perawatan yang tepat setelah berkomunikasi dengan konselor genetik akan meningkatkan kualitas kehidupan mereka.

Manusia normal dipandang sebagai makhluk unggulan yang sempurna Keunggulannya terletak pada wujud kejadiannya sebagai makhluk yang diciptakan dengan sebaik-baik penciptaan. Manusia yang 
tidak normal dan mempunyai kelainan genetika, merupakan tanda- tanda kekuasaan Allah SWT yang telah diterangkan dalam al-Qur'an dalam Qs. al-Hajj. Saudara saudara kita yang diciptakan oleh Allah SWT dengan segala kekurangannya bukan sebagai bahan-bahan olok-olok, tapi harus dibantu dengan bekal ilmu pengetahuan yang dimiliki oleh manusia normal dan saling menghargai satu sama lain, sebagaimana dalam Qs. alHujurat: 11, yang artinya :"Hai orang-orang yang beriman, janganlah suatu kaum mengolok-olok kaum yang lain (karena) boleh jadi mereka (yang diolok-olok) lebih baik dari mereka (yang mengolok-olokan) wanita yang lain (karena) boleh jadi wanita (yang diolok-olokan) lebih baik dari wanita (yang mengolok-olokan) dan janganlah kamu mencela dirimu sendiri dan janganlah kamu panggil memanggil dengan julukan yang buruk" (Qs. al- Hujurat: 11).

Telah diterangkan juga dalam Qs. al-Nisa ayat 148 - 149, yang artinya: Allah tidak menyukai ucapan buruk, (yang diucapkan) dengan terang kecuali oleh orang yang dianiaya. Allah adalah Maha Mendengar lagi Maha Mengetahui. Jika kamu menyatakan sesuatu kebaikan atau menyembunyikan atau memaafkan sesuatu kesalahan (orang lain), maka sesungguhnya Allah Maha Pema`af lagi Maha Kuasa.

Manusia yang diciptakan sempurna dan normal wajib selalu bersyukur atas segala kenikmatan yang telah Allah SWT limpahkan kepadanya. Tugas manusia normal untuk membantu sesamanya yang berkekurangan dengan inisiatif moralnya untuk meningkatkan kualitas hidup sesamanya agar lebih baik. Pandangan Islam mengenai arti hidup, sangat berlainan dengan pandangan orang-orang yang berpandangan 
kebendaan samata-mata (materialistis). Dengan demikian tujuan hidup manusia menurut Islam adalah menyerahkan diri untuk mencapai kebahagiaan dunia, ahirat, jasmani, dan rohani, yang dalam pelaksanaannya, materi sebagai alat, sedangkan rohani sebagai pengaruh. Sehingga bagi orang orang yang kurang beruntung bisa jadi menjadi ladang amal ibadah kita. Dengan dilandasi ketaqwaan dan kecintaan kita kepada Allah SWT maka dengan ilmu pengetahuan yang manusia kuasai, pendidikan bagi orang yang menderita kelainan genetika, memahami kondisi psikososial penderita dan keluarganya akan sangat membantu. Meskipun masalah genetik dan fisik bagi penderita kelainan genetika tidak dapat diatasi, pendidikan, serta perawatan yang tepat setelah berkomunikasi dengan konselor genetik akan meningkatkan kualitas kehidupan mereka.

Pada dasarnya Allah SWT mencintai kebaikan dan membenci keburukan. Oleh karena itu setiap mu`min dituntut mengembangkan kebaikan, apakah dalam ucap sikap, maupun tindakan, bahkan dampaknya dalam segala kehidupan. Kebaikan yang mesti dikembangkan bukan hanya dalam cara, tapi juga dampaknya di hari kemudian.

\section{Kesimpulan}

Setelah melakukan pembahasan dan menganalisis dapat peneliti simpulkan bahwa kelainan genetik terjadi karena peristiwa nondisjunction yaitu kegagalan sepasang kromosom untuk memisahkan selama meiosis, yang merupakan proses di mana sel telur dan sperma 
mereplikasi diri dan membagi. Sedangkan dalam perspektif al-Qur'an manusia yang tidak normal dan mempunyai kelainan genetika, merupakan tanda-tanda kekuasaan Allah SWT. Saudara-saudara kita yang diciptakan oleh Allah SWT dengan segala kekurangannya bukan sebagai bahan-bahan olok-olok, tapi harus dibantu dengan bekal ilmu pengetahuan yang dimiliki oleh manusia normal dan saling menghargai satu sama lain.

\section{Daftar Pustaka}

Alresna, F. 2009. Karakteristik Dismorfologi dan Analisis Kelainan kromosom pada Siswa Retardasi Mental di SLB C/C1 Widya Bhakti Semarang. Karya Tulis Ilmiah. Semarang: Fakultas Kedokteran UNDIP.

Arnold, Edward. 1973. Towards The Understanding of the Mechanism of Heredity $3^{\text {rd }}$ Ed. London: Whitehouse HLK.

Ariani, Yulia. 2010. Konseling Genetik: Antara Kebutuhan dan Keterbatasan. Jakarta: Majalah Kedokteran Indonesia.

Campbell, N. A. et. Al. 2008. Biology: Concepts and Connections. San Franscisco: Banjamin-Cummings.

Fidler, Deborah J. 2005. The Emerging Down Syndrome Behavioral Phenotype in Early Childhood. Infant \& Young Children Journal. Vol .18 No. 2 pp 86-103.

Frias, Jaime L, MD, Marsha L, Davenport, MD. 2003. Health Supervision for Children With Turner Syndrome. Official Journal of American Academy of Pediatrics, doi : 10, 1542/peds.

Gardner, R.J McKinlay, Grant R Sutherland, Lisa G. Shaffer. Chromosome Abnormalities and Genetics Counseling $4^{\text {th }} \mathrm{Ed}$. Inggris: Oxford University Press Inc.

Green, Eric. D. Daniel L. Castner. 2011. National Genome Research Institute National of Health: Chromosome Abnormalities. Washington: NHGRI

Kingston, Helen M. 2002. ABC of Clinical Genetics $3^{\text {rd }}$ Ed. London: BMJ Book 
Knight, Julian C. 2003. Human Genetic Diversity $1^{\text {st }}$ Ed. New York: Oxford University Press

Koshland, D. 1994. Mitosis. Back to The Basics Cell Journal. Vol. 77:951-954

Mandal, Dr. Ananya. 2013. Chromosomal Abnormalities, Amsterdam: New Medical.

Santosa, Heru. 2009. Memahami Genetika dengan Mudah. Yogyakarta: Nuha Offset.

Suryo. 1995. Genetika Manusia. Yogyakarta: Gajah Mada University Press

Theisen, Aaron, Lisa G. Shaffer. 2010. Disorders caused by Chromosomes abnormalities, The Application of Clinical Genetics. London: Dove Medical Press Ltd.

Turnpenny, P, Sian E. 2007. Emery's Elements of Medical Genetics. Elsevier Journal. 12th ed.

Wellesley, Diana et.al. 2012. Rare Chromosome Abnormalities Prevalence and Prenatal Diagnosis Rate from Populated-based congenital anomaly registers in Europe. Europe Journal of Human Genetics. 20521-526 doi:10 1038/ejgh.2011.246.

Wiseman, Frances K, Kate A.Alford, Victor LJ Tybulewicjz and Elizabeth MC Fisher. 2009. Down Syndrom Recent Progress and Future Prospects. Human Molecular Genetics Journal. Vol. 18 Review Issue doi : 10, 1093/hmg/ddp.

Zaccharin, Margareth Dr. Ann Maquire. 2011. Hormones and Me: Klinefelter Syndrom. New Zealand: Australasian Paediatric Endocrine Group (APEG). 